\title{
屋根上積雪荷重の制御に滑落雪 ON THE TERM CONTROLLED BY 処理を用いる場合の制御日数に SNOW LOAD: PRACTICAL USE OF ついて ROOF-SNOW SLIDING
}

\section{高倉政寛 一 $* 1$ 千葉隆弘 - $* 2$ \\ 伊東敏幸 一 $* 3$ 苫米地 司 $-* 4$ \\ キーワード : \\ 勾配屋根, 滑落雪, 積雪荷重, 制御}

Keywords

Sloped roof, Snow sliding, Snow load, Control

\author{
Masahiro TAKAKURA -*1 \\ Toshiyuki ITO
}

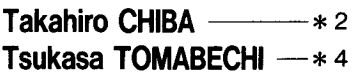

The phenomenon of accumulated snow sliding off a pitched roof of a building is frequently seen. The occurrence of snow sliding is affected by such factors as atmospheric temperature and temperature inside the attic. In this study, the following investigation was carried out in order to establish a method for evaluating snow load on a pitched roof that takes into account the occurrence of snow sliding. First, it examined about the characteristic of snow sliding resistance. It was found that the occurrence of snow sliding is greatly affected by adfreezing resistance and that this resistance decreases if the atmospheric temperature rises to $-2^{\circ} \mathrm{C}$ or higher. Next, from these results on adfreezing resistance, we used data on atmospheric temperature obtained from a weather station to calculate the number of days required for snow sliding to occur. In this paper, we propose a method for evaluating snow load on a roof that includes consideration of the number of days required for snow sliding to occur.

\section{1.はじめに}

多雪地域に建設される建築物は，降積雪現象がもたらす問題を除 外して計画することができない。特に大規模構造物の屋根上積雪荷 重は大きな外力となり，構造上の制約を受ける場合が多い。そのた め, 屋内スポーツ施設等の大空間を必要とする建築物では, この荷 重を積極的に制御する試みが行われている11,2)。このような考之方を 取り入れる場合は，何らかの方法で屋根雪を確実に処理する必要が ある。屋根上積雪荷重の評価について, 日本建築学会建築物荷重指 針・同解説（以下，荷重指針）をみると，実験や調查に基づいた検 討によって十分に信頼性のある屋根雪処理が可能な場合にのみ，そ の処理性能に応じた制御積雪荷重の採用を認めている31。さらに, 荷 重を制御する具体的な屋根雪処理方法の一つとして，積極的に雪を 滑落させる方法を挙げている。この勾配屋根をもつ建築物で頻繁に みられる滑落雪を利用する方法は, 処理に関する専用装置・熱源等 を必要としないこと，雪処理に関する人為的なミスが起こりにく いことから, 積雪荷重の制御を行う有効な屋根雪処理の一つと考之る。 滑落雪現象を利用して積雪荷重を制御する場合, この現象の発生 条件に関する十分な検討を行っておく必要がある。既往の研究によ れば, 滑落雪現象を妨げる抵抗力は外気温や小屋裏温度等の温度指 標に依存している4〉。すなわち, 外気温や小屋裏温度等の推移を検討 することで，滑落雪現象の発生に要する日数が明らかとなり，その 日数内の積雪荷重を算出できると考之る。

このようなことから本研究では，勾配屋根における滑落雪現象の 発生を考慮した屋根上積雪荷重の評価手法を確立するための試みと して, この屋根における滑落雪の発生に必要な条件を外気温を指標 として整理した。この結果を基に, 滑落雪現象の発生に要する日数
を気象官署の地点別に統計処理した。これらのことから，屋根上積 雪荷重の制御を行う場合の制御日数について考察した。

\section{2. 研究の方法}

\section{1 滑落雪の発生に必要な基本的な温度条件}

滑落雪現象を利用した屋根上積雪荷重の評価を行う場合，滑落雪 現象の発生に至るまでの屋根上積雪状況を予測することが極めて重 要となる。具体的には，屋根上に堆積する雪が荷重として建築物に 加わる継続日数（滑落雪現象の発生までに要する日数）とその日数 に積もり得る積雪量を把握しておく必要がある。

ここで，滑落雪現象の特徵について，既往の屋根上積雪観測結果 をみると，滑落雪現象は塗装鋼板葺き (屋根勾配 30 ，無暖房)の屋根 で $+1^{\circ} \mathrm{C}$ 以上，膜材 (屋根勾配 20 および 30 ，無暖房)ではー2 0 $0^{\circ} \mathrm{C}$ の範囲で顕著に発生している1),2)。さらに, 屋根雪の滑落現象の発生 に大きく関わる落雪事故の発生日をみると，この事故は，日最高気 温がー $3^{\circ} \mathrm{C}$ 以上の日に集中している5)。すなわち，滑落雪現象の発生 は, 温度指標に大きく依存しており，その指標について明らかにする ことで，勾配屋根における積雪荷重の推移を検討できると考える。

積雪荷重の推移に関わる検討を行うためには，滑落雪現象を支配 している諸抵抗力について整理しておく必要がある。ここで，諸抵 抗力の特徵について述べると次のようになる。屋根雪の滑落雪現象 を支配する諸抵抗力には，連続的な屋根雪の破断を抑止する雪塊相 互の破断抵抗力と屋根雪と屋根葺材との間に発生する界面抵抗力が ある。前者の抵抗力には，積雪の引張およびせん断抵抗力があり， この破断抵抗力は屋根形状の工夫, 屋根面の温度分布を均一にする こと等で, 低減もしくは解除することが可能である ${ }^{6)}$ 。後者の界面抵
*1 北海道工業大学大学院 大学院生・修士 (工学)

(二006-8585 札幌市手稲区前田 7 条15丁目4-1)

*2 北海道工業大学大学院 大学院生

*3 北海道工業大学建築工学科 講師 - 博士 (工学)

*4 北海道工業大学建築工学科教授・工博
*1 Graduate Student, Hokkaido Inst. of Tech., M. Eng.

*2 Graduate Student, Hokkaido Inst. of Tech

*3 Lecturer, Hokkaido Inst. of Tech., Dr. Eng.

*4 Prof., Hokkaido Inst. of Tech., Dr. Eng. 
抗力には, 滑雪開始への抵抗力として作用する凍着抵抗力や静摩擦 抵抗力, 滑雪持続への抵抗力として作用する動摩擦抵抗力がある。 ここで,これら 3 つの界面抵抗力のうち, 凍着抵抗力について既往の 研究 ${ }^{4), 7,8), 9}$ から得られる結果を整理すると図一1になる。図のよう に, 凍着抵抗力は実験方法等によって大きな違いがあるものの, 屋 根用塗装鋼板の $-10^{\circ} \mathrm{C}$ の実験温度では，いずれの研究でも $200 \mathrm{~kg} /$ $\mathrm{m}^{2}$ 以上となる。例之ば, 屋根勾配 30'の建築物でこのような凍着抵抗 力が作用すると, 滑落の発生に必要な屋根上積雪媣は $1.3 \mathrm{~m}(\sin \theta \times$ 積雪の単位重量 $\div$ 凍着抵抗力 $\left.=\sin 30^{\prime} \times 300 \mathrm{~kg} / \mathrm{m}^{3} \div 200 \mathrm{~kg} / \mathrm{m}^{2}\right)$ 以上 となる。一方, 凍着抵抗力は $-2^{\circ} \mathrm{C}$ 以上の温度となれば, この值が急 減する傾向がみられる。これらの結果をみると, 外気温が低温の場 合は, 凍着抵抗力が屋根雪の滑落雪現象の発生を大きく支配してい るため，この現象を期待することが難しい。一方，プラス温度の外 気温になると凍着抵抗力が低減することから, 滑落雪現象が発生し やすい状況になると考える。

\section{2 滑落雪現象の発生に要する日数}

先に示したように，屋根雪の滑落雪現象の発生は，凍着抵抗力に 大きく支配されている。従って，凍着抵抗力の大小に影響を及ぼす 温度条件を整理することで, 滑落雪現象の発生に要する日数を検討 することが可能と考える。このようなことから，外気温の推移を指 標として, 滑落雪の発生に要する日数を算出した。ここで, 荷重指 針をみると積雪荷重の評価方法は，屋根上積雪の制御を積極的に行 わない場合と，積極的に行う場合とで以下のように異なる。前者は， 降雪が累積された積雪哚（年最大積雪梁）を用いるのに対し, 後者 では，屋根雪処理の性能に応じた期間内に積もり得る最大の積雪深 (年最大 7 日增分積雪深) を用いて評価することが可能となってい る。そのため本研究では, 算出して得られた日数から荷重指針の年 最大 7 日増分積雪梁の適用圈域について検討した。

滑落雪の発生に要する日数は図一2に示す仮定を基に算出した。 凍着抵抗力は, 図一 1 で示したように $+2^{\circ} \mathrm{C}$ の温度で $4 \mathrm{~kg} / \mathrm{m}^{2}$ 程度作 用するケースが測定されているものの，この抵抗力は水分が凝固し て屋根葺材に付着することが発生の要因であるので， $0^{\circ} \mathrm{C}$ が作用す るか否かの境目と考える。このことから, 凍着抵抗力は, $-2 \sim 0^{\circ} \mathrm{C}$ の 温度になると急減し， $0^{\circ} \mathrm{C}$ 以上になると作用しないと暫定的に仮定 した。この温度条件を図中に示したように 3 ランクに分けて, 日最高 気温が各ランクの境界温度以下になったときには, 凍着抵抗力が作 用して滑落雪現象が発生しないこととした。ここで，前述の通り， 屋根雪が滑落する際には静・動摩擦抵抗力が作用する。これについ て本研究では, 滑落雪の条件を単純化するために, 屋根勾配 $\theta$ と静. 動摩擦係数 $\mu \mathrm{s}, \mu \mathrm{k}$ との間に $\sin \theta>\mu \mathrm{s}$ および $\sin \theta>\mu \mathrm{k}$ が成立し, 凍 着抵抗力が解除されると滑落雪現象が発生する屋根を想定してい る。従って, 実際の荷重評価に当たっては屋根幕材の表面性状や雪 質が摩擦抵抗力に及ぼす影響10),11)について十分に考慮した屋根勾配 の設定を行っておく必要がある。

以上に示した仮定の基で, 屋根上に雪が継続して堆積する日数の 各年極值を気象資料から抽出した。なお，抽出に用いた資料は，気 象官署 148 力所における 33 年間 (1962 1994 年)の観測值が収録さ れているSDPデータである。

\section{3 再現期待値の算出}

屋根上に雪が継続して堆積日数は, 積雪荷重の評価に大きく関わ
る事象であることから, 本来であれば, 設計される建築物の耐用年 数以上の気象資料が確保されている状況下で, その資料を統計処理 することが望ましい。しかし, 統一的な方法で観測された気象資料 で入手可能なものは, 一般的な建築物の耐用年数よりも観測期間が 短いことから, 先に示した SDP データから得られる堆積日数の各年 極值を用いて再現期待值を算出した。再現期待値は, Gumbel 確率紙 上に 33 年分の各年極值をプロットし, そのプロット值を直線回帰し て算出した。なお，再現期間值は，荷重指針で基本とされている再 現期間 100 年に対する值とした。

\section{3.研究の結果}

\section{1 滑落雪現象の発生に要する日数の各年極値}

滑落雪現象の発生に要する日数の各年極值を Gumbel 確率紙上に プロットした結果の一例をみると四一3となる。図のように, 札幌の 場合は，極値がほぼ直線的な分布であることから，33 年間分のプ ロット值全てを直線回帰して，100 年再現期待値を算出することが できる。一方，釧路の場合では，極值が直線的に分布していないた め, 札幌と同様の方法で回帰すると, 再現期間が長い場合, 過小評 価することとなる。このように, 滑落雪現象の発生に要する日数は, 地点ごとに極值分布（プロット值の分布）が異なっているため，そ の分布の差異に対応させて再現期待值を算出することが必要とな る。ここで，地点の違いによって極値分布の形状が異なることが指
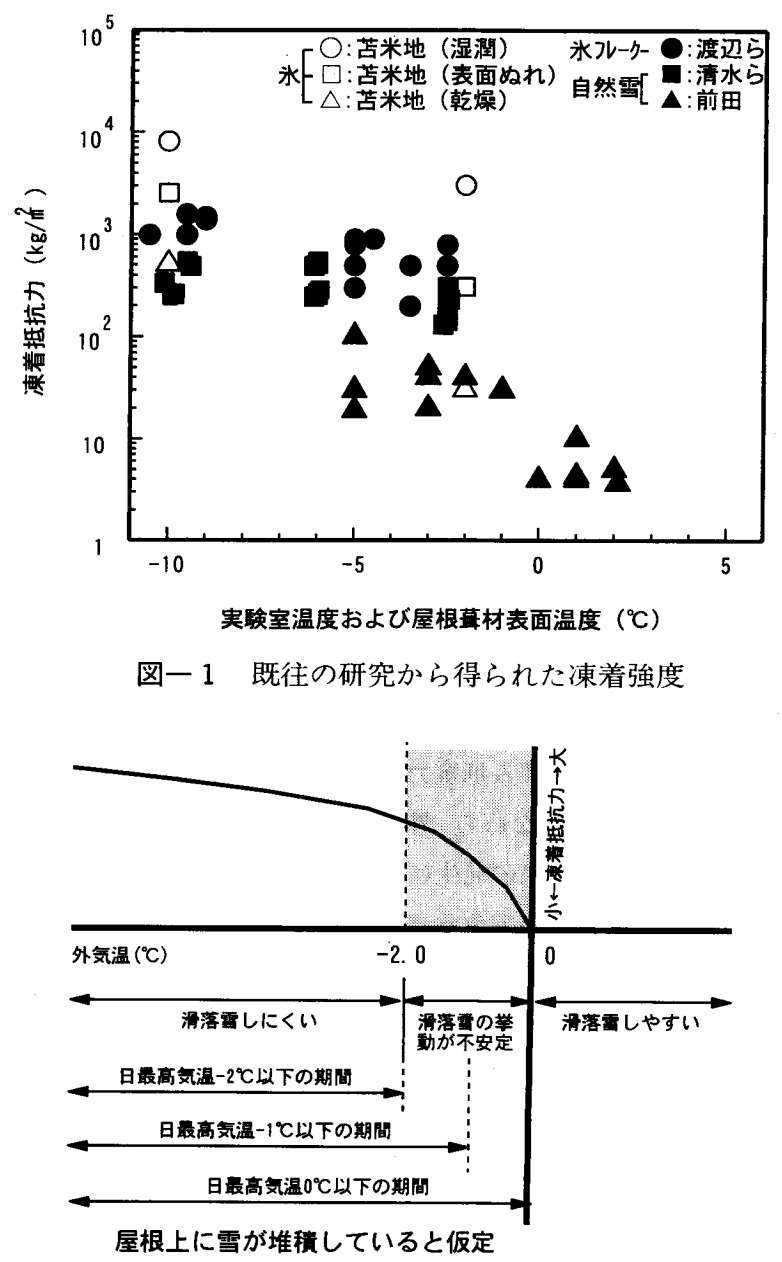

図一2＼cjkstart滑落雪の発生に要する日数の算出仮定 
摘されている年最大積雪梁では,この違いに関して, 極値上位 $1 / 3$ の プロット值のみを直線回帰することで，再現期待值を算出する方法 が提案されている ${ }^{12)}$ 。この方法に従って再現期待值を算出した結果 をみると図一 4 になる。この図から得られる再現期待值は, 再現期間 2 年 (非超過確率 50\%) のようにその期間が極めて短い場合，再現期 待值がプロット值を下回る場合があるものの, 再現期間 100 年(非超 過確率 99\%）に対する值を得る場合, 図一3で示した式に比べてブ ロット值に近似した再現期待值を得ることができる。屋根上積 雪の堆積日数は, その値が積雪荷重の評価に用いられる場合, 非超過 確率 $50 \%$ のような平年的な数值が要求されるのではなく, 耐用年数中 に起こり得る最大值が必要とされる。このことから, 以下の検討では 屋根に雪が継続して堆積する日数として極值上位 $1 / 3$ のプロット值 のみを直線回帰して得られる 100 年再現期待值を用いることとした。

\section{2 地点別にみた滑落雪現象の発生に要する日数}

滑落雪現象の発生に要する日数，すなわち屋根上積雪の堆積期間 の 100 年再現期待値が 7 日以上となる観測地点を表一 1 に示す。表 中の雄武における $\mathrm{t}($ 日最高気温 $) \leqq 0.0^{\circ} \mathrm{C}$ の継続日数をみると 99 日 となるため, 3 力月以上屋根上に雪が堆積することになる。このよj に, 屋根面に 7 日以上雪が堆積する地点は, $\mathrm{t} \leqq 0.0^{\circ} \mathrm{C}$ の場合 27 地点
である。なお，いずれの温度条件でも北海道と東北の場合，全観測 地点中 37 地点, $\mathrm{t} \leqq-1.0^{\circ} \mathrm{C} の$ 場合 33 地点, $\mathrm{t} \leqq-2.0^{\circ} \mathrm{C} の$ 場合 27 地 点である。なお，いずれの地点条件でも北海道と東北の北部が 7 日以 上屋根面に雪が堆積する結果となった。

表ー1に示した観測地点を日本地図上にプロットすると困一 $5 に$ なる。図中の○印の地点は, 滑落雪現象の発生条件となる各温度ラ ンク以下の継続日数が 7 日未満となり, 屋根上に 7 日以上雪が堆積 しないことを示している。すなわち，荷重指針に示されている滑落 雪現象を利用した制御積雪荷重（年最大 7 日増分積雪深を用いた評 価)の適用が可能な地点であると考える。次に, $\mathrm{t} \leqq 0.0^{\circ} \mathrm{C}$ の継続日数 が7日以上になる地点をみると, 該当する地点は全観測地点中の $25 \%$ となり，豪雪地带対策特別措置法に指定されている地域の約 76\%を占める。これらの地点は 7 日以内に滑落雪が見込めないため, 信頼性の高い人工的な制御を行わない限り，年最大 7 日增分積雪深 を用いた積雪荷重の評価ができない。しかし，これらの地点におけ る継続日数をみると, 北海道以南では継続日数が 10 日前後となる地 点が多く, 冬期間に何回かの滑落雪が発生することになる。このこ とから, 屋根雪が自然に滑落する外気温を適切に評価できる場合は, これらの継続日数に対応する積雪量を用いることで積雪荷重の評価
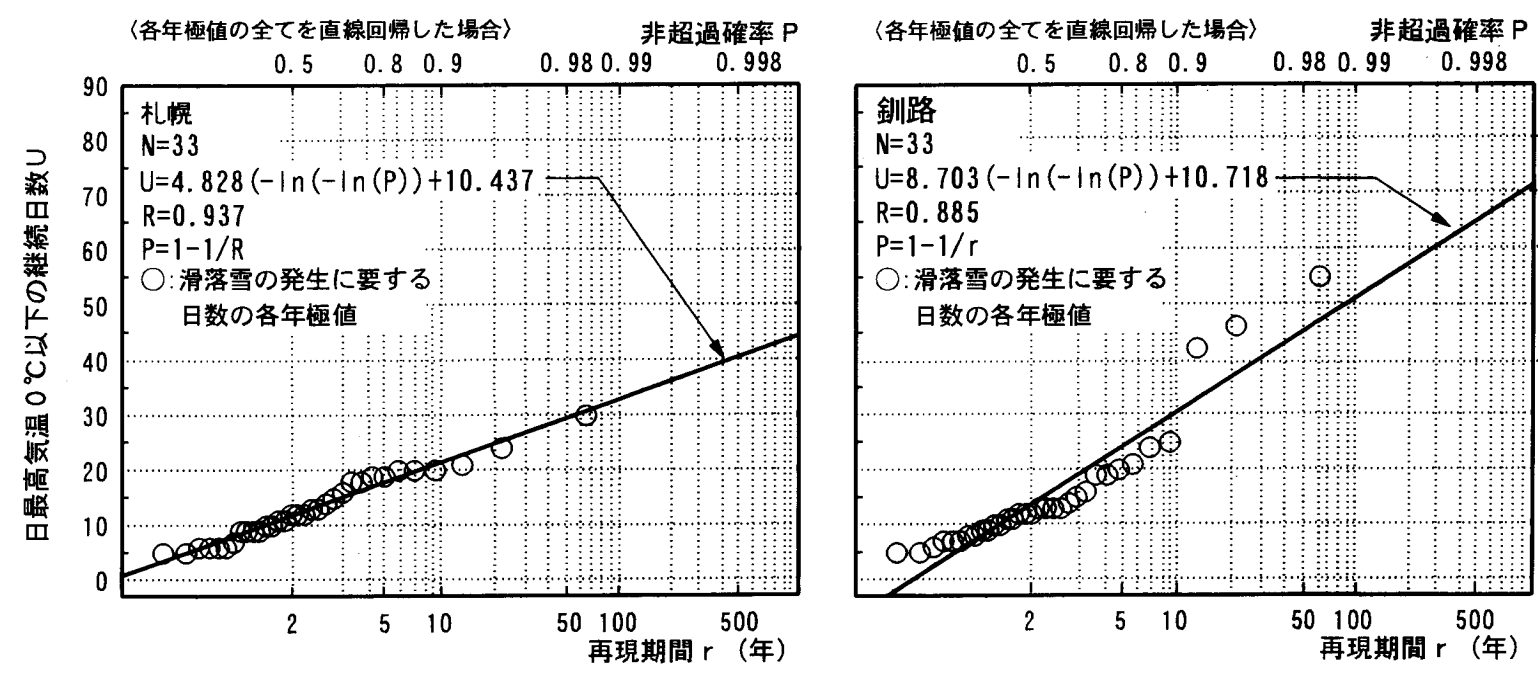

図ー3 滑落雪の発生に要する日数の各年極值と再現期待值（各年極值の全てを直線回帰した場合）
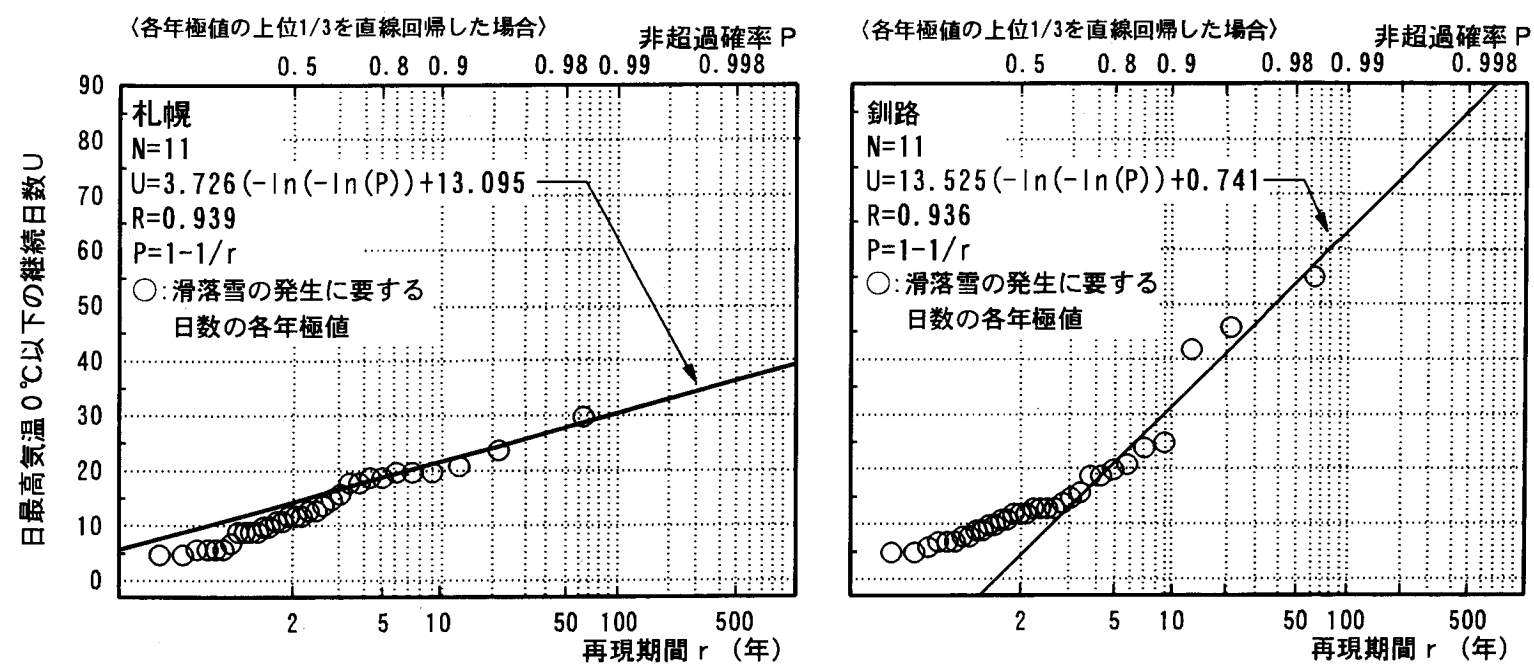

図一 4 滑落雪の発生に要する日数の各年極值と再現期待値（極值上位 $1 / 3$ の值のみを直線回㷌した場合） 

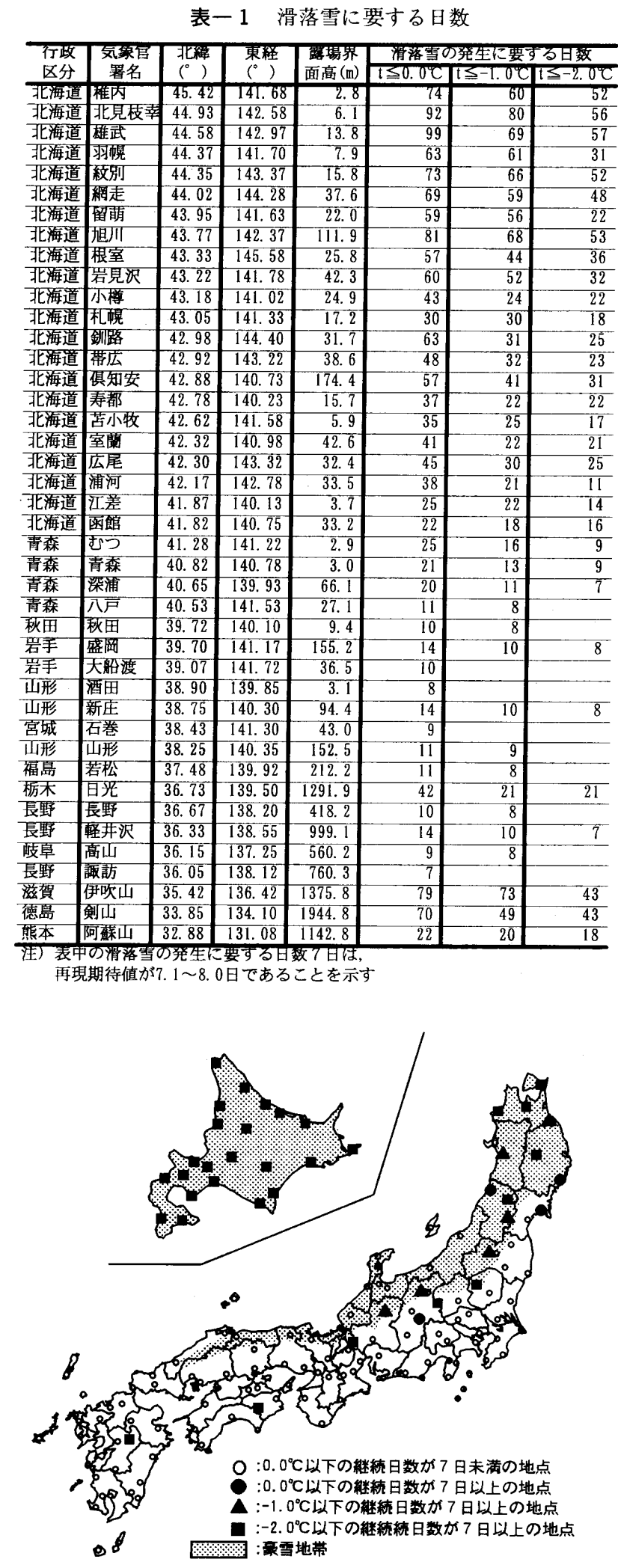

図一 5 滑落雪の発生に要する日数の地理的な分布

を行うことが可能と考える。

一方，人工的な滑落雪制御を行う建築物において7日増分積雪深 を用いた積雪荷重の評価をする場合には，次のことが言える。継続 日数は, $\mathrm{t} \leqq-1.0^{\circ} \mathrm{C}, \mathrm{t} \leqq-2.0^{\circ} \mathrm{C}$ と外気温ランクが下がるに伴って 7 日未満となる地点が増加する。これらの地点では, 各外気温ランク の以下の日に人工的な制御を用いて，7 日以上の期間にわたって凍 着抵抗力が発生しないよjにする必要がある。このことによって， 荷重指針に示されている制御積雪荷重を適用することが可能になる と考之る。

このように，外気温の推移から得られる継続日数は，自然滑落雪 あるいは，人工的な制御による滑落雪現象を捉える有効な指標にな り得ると考える。

\section{4.まとめ}

本研究では, 勾配屋根における滑落雪現象の発生を考虑した屋根 上積雪荷重の評価手法を確立するための試みとして，滑落雪の発生 と外気温との関係を既往の研究から整理した。整理して得られた仮 定を基に，外気温を指標として滑落雪に要する日数を算出した。そ の結果，屋根雪を積極的に滑落させる場合に用いられる制御積雪荷 重 (年最大 7 日増分積雪深) の適用地域・適用条件が明らかになった と同時に, 屋根雪が自然滑落するために必要な日数が明らかとなっ た。本研究で得られた結果は，一仮定を基に検討を行っているので 実用に耐之得る段階には到達していないものの，今後の検証・調查 等で滑落雪の発生する温度条件が十分に明らかとなれば，勾配屋根 における屋根上積雪荷重の評価に寄与できると考之る。

なお，本研究の一部は，1996-97 年度文部省科学研究費基盤研究 C（代表者：苫米地 司）で実施したものである。

\section{参考文献}

1）倉橋 勲, 他 4 名：(仮称) 但馬ドームの積雪荷重の検討, 日本 建築学会技術報告集，第 5 号, pp.91-95, 1997.12

2）苫米地 司, 他 4 名：膜構造建築物における屋根上積雪荷重評 価について, 日本建築学会技術報告集, 第 5 号, pp.31-36, 1997.12

3）日本建築学会編：建築物荷重指針・同解説, pp.168-235, 1993

4）前田博司：金属板屋根における積雪の滑落, 日本雪水学会誌, 第 41 巻 3 号, pp.199-204, 1979.9

5）山形敏明, 苫米地 司：屋根雪の落雪事故の発生要因について, 第 12 回日本雪工学会大会論文報告集, pp.35-38, 1996.1

6）苫米地 司, 他 3 名：屋根雪の滑雪現象に関する基礎的研究, 日 本雪工学会誌, Vol. 11, No. 2, pp.2-9, 1995.4

7）清水增治郎, 木村忠志：氷点下における雪の屋根材への付着, 日本雪水学会誌，第 54 巻 3 号, pp.269-275, 1992.9

8）渡辺正朋：屋根莫材と雪水との凍着強さに関方石研究, 第 9 回 日本雪工学大会論文報告集, pp.127-130, 1993.1

9）苫米地 司，伊東敏幸：屋根上積雪荷重の制御に関する基礎的 研究，日本雪水学会誌，第 56 巻 3 号, pp.215-222, 1994.9

10）渡辺正朋，平井和喜：屋根莫材と雪水の摩擦に関する研究，日 本雪工学会誌，第 9 号, pp.4-15, 1988.12

11）高倉政寞，伊東敏幸，苫米地 司：経時的に雪質の変化した屋 根上積雪と塗装鋼板との摩擦特性，日本建築学会構造系論文集 第 510 号，pp.45-50, 1998.8

12）和泉正哲, 三橋博三, 高橋 徹: 年最大積雪樑の確率統計的性 質と再現期間推定法, 日本建築学会構造系論文集第 390 号, pp. 49-58, 1988.8

[1998年 6 月24日原稿受理 1998年11月 4 日採用決定］ 